\title{
TINGKAT KEBUGARAN JASMANI ANAK PUTRA DI PANTI SOSIAL ASUHAN ANAK WILLIAM BOOTH MEDAN
}

\author{
Oleh \\ Nurhayati Simatupang ${ }^{1}$, Kristanto Marganda Nainggolan ${ }^{1}$ \\ ${ }^{1}$ Fakultas Ilmu Keolahragaan Universitas Negeri Medan \\ Email: kmpnainggolan02@gmail.com
}

\begin{abstract}
Abstrak
Tujuan penelitian ini untukmengetahui tingkat kebugaran jasmani anak putra di Panti Sosial Asuhan Anak William Booth Medan.Penelitian ini dilaksanakan di Fakultas Ilmu Keolahragaan Universitas Negeri Medan Jln. William Iskandar Psr. V-Medan. Populasi dalam penelitian ini adalah seluruh anak putra di Panti Sosial Asuhan Anak William Booth Medan yang berjumlah 45 orang. Sampel dalam penelitian ini adalah seluruh anak putra yang masing-masing dibagi berdasarkan kelompok umur, anatara lain umur 6-9 tahun, umur 10-12 tahun, umur 13-15 tahun dan umur 16-19 tahun.Teknik pengambilan sampel dengan menggunakan total sampling dan menggunakan metode penelitian deskriptif dengan metode survei. Teknik analisis data yang digunakan adalah statistik kuantitatif dengan persentase guna menentukan klasifikasi tingkat kebugaran jasmaninya. Berdasaran analisis data diperoleh bahwa tingkat kebugaran jasmani anak putra di Panti Sosial Asuhan Anak William Booth medan berada dalam klasifikasi "sedang". Hal ini dapat dilihat dari jumlah persentase dalam klasifikasi kebugaran jasmani "sedang" pada anak putera kelompok umur 6-9 tahun yaitu 75\% (6 orang), pada kelompok umur 10-12 tahun sebesar 70\% (7 orang), pada kelompok umur 13-15 tahun sebesar 81,8\% (9 orang) dan pada kelompok umur 15-19 tahun sebesar $68,75 \%$ (11 orang).
\end{abstract}

Kata Kunci: Kebugaran jasmani, Anak.

\section{A. PENDahuluan}

Setiap manusia dalam melakukan aktifitas sehari-hari memerlukan kondisi fisik yang baik. Kebugaran Jasmani adalah kesanggupan dan kemampuan tubuh melakukan penyesuaian (adaptasi) terhadap pembebasan fisik yang diberikan kepadanya (dari kerja yang dilakukan sehari-hari) tanpa menimbulkan kelelahan yang berlebihan. Setiap orang membutuhkan kebugaran jasmani yang baik, agar ia dapat melaksanakan pekerjaannya dengan efektif dan efisien tanpa mengalami kelelahan yang berarti. Tidak menimbulkan kelelahan yang berarti maksudnya ialah setelah seseorang melakukan suatu kegiatan atau aktifitas, masih mempunyai cukup semangat dan tenaga untuk menikmati waktu senggangya, dan untuk keperluan-keperluan lainnya yang mendadak (Muhajir,2007:57). 
Kebugaran jasmani dapat dibagi dalam dua aspek yaitu : 1) kebugaran jasmani yang berhubungan dengan kesehatan, 2) kebugaran jasmani yang berhubungan dengan keterampilan (prestasi). Kebugaran jasmani yang berhubungan dengan kesehatan meliputi : a) Daya tahan jantung dan paru-paru, b) kekuatan otot, c) daya tahan otot, d) fleksibilitas dan e) komposisi tubuh. Sedangkan kebugaran jasmani yang berhubungan dengan keterampilan (prestasi) meliputi : a) kecepatan, b) power, c) keseimbangan, d) kelincahan, e) koordinasi dan f) keceptan reaksi. (Nurhasan, 2001:132).

Kebugaran jasmani berperan penting dalam mengembangkan kemampuan, kesanggupan dan daya tahan diri sehingga dapat mempertinggi daya tahan diri sehingga dapat mempertinggi daya aktivitas kerja maupun belajar. Latihan kondisi fisik (physical conditioning) memegang peranan yang sangat penting untuk mempertahankan atau meningkatkan derajat kebugaran jasmani (physical fitness). Derajat kebugaran jasmani seseorang sangatlah menentukan kemampuan fisiknya dalam melaksanakan tugastugasnya sehari-hari. Semakin tinggi derajat kebugaran jasmani seseorang maka semakin tinggi pula kemampuan kerja fisiknya. Dengan kata lain, hasil kerjanya kian produktif jika kesegaran jasmaninya semakin meningkat.

Untuk meningkatkan fisik dan psikis seseorang kearah yang lebih baik lagi, salah satu jalan terbaik adalah dengan melakukan olahraga secara teratur dan berkesinambungan. Dengan olahraga secara teratur dan berkesinambungan diharapkan akan mempengaruhi kondisi badan seperti peningkatan dalam kekuatan, kelentukan dan stamina, kecepatan reaksi serta pemulihan yang lebih cepat dari organ-organ tubuh setelah latihan. Apabila seseorang memiliki keadaan tubuh yang segar salah satu aspek pokok yang tampak adalah keadaan penampilan jasmaninya. Pada orang yang mempunyai tingkat kebugaran jasmani yang baik tentu kita akan menjumpai seseorang yang memiliki tubuh yang fit dimana ketika melakukan berbagai aktifitas maka aktifitas tersebut dilakukan dengan penuh energi.

Kebugaran jasmani dapat dikelompokkan sebagai berikut : (a) kekebalan terhadap serangan berbagai macam penyakit; (b) kekuatan dan ketahanan otot; (c) ketahanan cardiorespiratory; (d) daya otot (muscular power); (e) fleksibilitas; (f) kecepatan; (g) kelincahan; (h) koordinasi; (i) keseimbangan; (j) ketepatan (Harsono, 1988:134). 


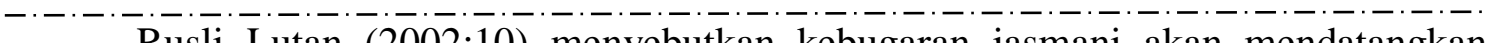

Rusli Lutan (2002:10) menyebutkan kebugaran jasmani akan mendatangkan manfaat di antaranya, terbangunnya kekuatan dan daya tahan otot seperti kekuatan tulang, persendian yang akan mendukung performa baik dalam aktivitas olahraga maupun non-olahraga, meningkatkan daya tahan aerobik, meningkatkan fleksibilitas, membakar kalori yang memungkinkan tubuh terhindar dari kegemukan, mengurangi stres dan meningkatkan gairah hidup.

Hasnan Said (1975:3) mengatakan "seseorang berada dalam keadaan fit, memiliki jasmani yang baik adalah orang-orang yang cukup mempunyai kekuatan (strenght), kemampuan (ability), kesanggupan, daya kreasi dan daya untuk melakukan pekerjaannya dengan efisien tanpa menimbulkan kelelahan yang begitu berarti”. Hal ini juga berlaku bagi setiap anak, di mana seorang anak juga harus memiliki kebugaran jasmani untuk dapat melakukakan aktivitas sehari-harinya seperti bermain, belajar dan melakukan pekerjaan rumahnya.

UU RI No. 35 tahun 2014 tentang Perubahan Atas UU NO. 23 Tahun 2002 tentang Perlindungan Anak Pasal 1 ayat 1 menyatakan bahwa anak adalah seseorang yang belum berusia 18 (delapan belas) tahun, termasuk anak yang masih dalam kandungan. Setiap anak berhak atas kelangsungan hidup, tumbuh dan berkembang serta berhak atas perlindungan dari kekerasan dan diskriminasi. Semua anak memiliki hak untuk bugar. Bugar adalah kemampuan tubuh untuk melakukan kegiatan sehari-hari tanpa menimbulkan kelelahan fisik dan mental yang berlebihan.

Karakteristik anak dikatan bugar yaitu apabila memiliki fisik yang aktif bergerak, inisiatif tinggi, dapat mengisi waktu luang. Juga memiliki mental yang kuat, percaya diri, berpikiran positif, kreatif, dan tidak sering sakit. Adapun faktor-faktor yang mempengaruhi kebugaran jasmani meliputi makanan, olahraga atau latihan, dan istirahat yang cukup.

Dalam beberapa keadaan tertentu keluarga tak dapat menjalankan fungsinya dengan baik dalam pemenuhan kebutuhan anak, yang kemudian menyebabkan keterlantaran pada anak. Menurut ( UU RI No. 4/1979, tentang kesejahteraan anak Bab 1 pasal 1) "Anak terlantar adalah anak yang karena sesuatu sebab orang tuanya tidak dapat menjalankan kewajibannya sehingga kebutuhan anak tidak dapat terpenuhi dengan wajar baik secara rohani, jasmani maupun sosial”. Oleh karena itu, menurut UU RI No.35 tahun 2014 dan UU RI No. 23 tahun 2002, pemerintah wajib memberi 
perlindungan dan memberi rasa aman dan nyaman serta memenuhi hak-hak setiap anak, supaya setiap anak mendapat kehidupan yang layak.

Panti Sosial Asuhan Anak (PSAA) William Booth Bala Keselamatan Medan merupakan salah satu lembaga swasta yang menjalankan program pemerintah untuk mengatasi permasalahan seperti memberikan bimbingan, pelayanan, dan penyantunan anak terlantar dan memiliki fungsi sebagai pengganti peranan orang tua dalam memenuhi kebutuhan mental dan sosial pada anak asuh agar mereka memiliki kesempatan yang luas untuk mengalami pertumbuhan fisik dan mengembangkan pemikiran hingga ia mencapai tingkat kedewasaan yang matang dan mampu melaksanakan peranan- perannya sebagai individu dan warga negara didalam kehidupan bermasyarakat (Keputusan Menteri Sosial RI No.59 huk 2003).

PSAA William Booth Bala Keselamatan Medan memiliki banyak peraturan dan jadwal kegiatan yang harus dilakukan oleh setiap anak asuhan. Anak-anak asuhan juga memiliki jadwal kegiatan di sekolah, seperti belajar, mengerjakan tugas, mengikuti mata pelajaran dan lain-lain. Setiap anak memiliki tugas dan tanggung jawab yang berbedabeda yang diberikan pengelola panti asuhan dan harus melaksanakan hal tersebut dengan baik.

Dengan memiliki kebugaran jasmani yang baik, anak-anak asuhan diharapkan mampu mengerjakan seluruh aktivitas di panti asuhan, mengikuti pelajaran di sekolah dengan baik, tidak mudah terserang penyakit dan lebih bersemangat. Meskipun anakanak panti adalah anak yang memiliki kebutuhan khusus, baik dari segi mental, sosial dan material, mereka juga harus memiliki kondisi fisik dan tingkat kebugaran yang baik. Mereka juga harus menjadi anak yang bugar, supaya mereka dapat melaksanakan tugas dan seluruh aktifitasnya dengan baik.

\section{B. METODE PENELITIAN}

Penelitian ini dilakukan di PSAA William Booth Bala Keselamatan Medan, Jalan Yos Sudarso No.10 Lorong 1 A Medan.Penelitian ini menggunakan metode penelitian deskriptif dengan teknik survei. Populasi dalam penelitian ini adalah seluruh jumlah anak yang berada di PSAA William Booth Medan yang berjumlah 45 orang. Penelitian mengambil sample dengan cara total sampling yaitu seluruh jumlah populasi.

Instrumen penelitian adalah TKJI (Tes Kebugaran Jasmani Indonesia) untuk anak dari Pusat Pengembangan Kualitas Jasmani Kementerian Pendidikan Nasional 
tahun 2010. Sample dibagi menjadi 4 berdasarkan kelompok umur yaitu umur 6-9 tahun, umur 10-12 tahun, umur 13-15 tahun dan umur 16-19 tahun.

Setiap kelompok umur akan diberikan rangkaian tes TKJI yang terdiri atas 5 tes, yang memiliki ketentuan yang berbeda berdasarkan setiap kelompok umur, meliputi: lari cepat; tes gantung siku tekuk/angkat tubuh; baring duduk; loncat tegak dan lari jarak menengah. Setiap kelompok umur harus melaksanakan 5 item tes TKJI, kemudian akan dilakukan pencatatan hasil dari setiap tes. Data diolah dengan menggunakan program SPSS 20 dengan menggunakan uji validitas dan statistik kuantitatif dengan persentase.

\section{HASIL DAN PEMBAHASAN PENELITIAN}

\section{HASIL PENELITIAN}

Data diperoleh dari hasil Tes Kebugaran Jasmani Indonesia (TKJI) terhadap subyek penelitian secara langsung yaitu pada 45 orang anak putra di Panti Sosial Asuhan Anak William Booth Medan, yang terdiri dari kelompok usia 6-9 tahun berjumlah 8 orang, 10-12 tahun berjumlah/10 orang, usia 13-15 tahun berjumlah 11 orang dan usia 16-19 tahun berjumlah 16 orang.

\section{Tabel 1}

Distribusi Frekuensi Kelompok Usia Anak Putra di Panti Sosial Asuhan Anak William Booth Medan

\begin{tabular}{cccc}
\hline No. & Kelompok Usia & Frekuensi & Persentase \\
\hline 1 & $6-9$ tahun & 8 & 17,8 \\
2 & $10-12$ tahun & 10 & 22,2 \\
3 & $13-15$ tahun & 11 & 24,4 \\
4 & $16-19$ tahun & 16 & 35,6 \\
\hline & Jumlah & 45 & 100,0
\end{tabular}

Berdasarkan hasil distribusi frekuensi, diketahui bahwa anak putra di Panti Sosial Asuhan Anak William Booth Medan yang berada pada kelompok usia terbanyak adalah kelompok usia 16-19 tahun yaitu sebanyak 16 orang (35,6\%), sedangkan yang berada pada kelompok usia paling sedikit adalah kelompok usia 6-9 tahun sebanyak 8 orang $(17,8 \%)$. 
Hasil TKJI (Tes Kebugaran Jasmani Indonesia) anak putra di Panti Sosial Asuhan Anak William Booth Medan, sebagai berikut:

a. Lari Cepat (Sprint)

Tabel 2

Hasil TKJI Lari Cepat

\begin{tabular}{ccccccccc}
\hline \multirow{2}{*}{ Nilai } & \multicolumn{2}{c}{$\begin{array}{c}\text { Usia 6-9 thn } \\
(30 \text { meter })\end{array}$} & \multicolumn{2}{c}{$\begin{array}{c}\text { Usia 10-12 thn } \\
(40 \text { meter })\end{array}$} & \multicolumn{2}{c}{$\begin{array}{c}\text { Usia } 13-15 \text { thn } \\
(50 \text { meter })\end{array}$} & \multicolumn{2}{c}{$\begin{array}{c}\text { Usia 16-19 thn }(60 \\
\text { meter })\end{array}$} \\
\cline { 2 - 10 } & $\mathrm{F}$ & $\%$ & $\mathrm{~F}$ & $\%$ & $\mathrm{~F}$ & $\%$ & $\mathrm{~F}$ & $\%$ \\
\hline 5 & 8 & 100 & 10 & 100 & 11 & 100 & 16 & 100 \\
4 & 0 & 0,0 & 0 & 0,0 & 0 & 0,0 & 0 & 0,0 \\
3 & 0 & 0,0 & 0 & 0,0 & 0 & 0,0 & 0 & 0,0 \\
2 & 0 & 0,0 & 0 & 0,0 & 0 & 0,0 & 0 & 0,0 \\
1 & 0 & 0,0 & 0 & 0,0 & 0 & 0,0 & 0 & 0,0 \\
\hline Jumlah & 8 & 100 & 10 & 100 & 11 & 100 & 16 & 100 \\
\hline
\end{tabular}

Hasil tes lari cepat untuk kelompok usia 6-9 tahun dengan lari 30 meter sebanyak 8 orang $(100 \%)$ mendapat nilai 5 yaitu dengan waktu kurang dari 5,5 detik. Selanjutnya lari cepat untuk kelompok usia 10-12 tahun dengan/lari 40 meter sebanyak 10 orang (100\%) mendapat nilai 5 yaitu dengan waktu kurang dari 6,3 detik. Kemudian lari cepat untuk kelompok usia 13-15 tahun dengan lari 50 meter sebanyak 11 orang (100\%) mendapat nilai 5 yaitu dengan waktu kurang dari 6,7 detik dan yang terakhir untuk lari 60 meter pada kelompok usia 16-19 tahun sebanyak 16 orang (100\%) mendapat nilai 5 yaitu dengan waktu kurang dari 7,2 detik.

b. Gantung siku tekuk/angkat tubuh

Hasil tes gantung siku tekuk dilakukan pada anak usia 6-9 tahun dan usia 10-12 tahun. Sedangkan gantung angkat tubuh dilakukan pada anak usia 13-15 tahun dan 1619 tahun.

Tabel 3

Hasil TKJI Gantung Siku Tekuk/Angkat Tubuh

\begin{tabular}{ccccccccc}
\hline \multirow{2}{*}{ Nilai } & \multicolumn{2}{c}{$\begin{array}{c}\text { Usia 6-9 thn } \\
\text { (Siku tekuk) }\end{array}$} & \multicolumn{2}{c}{$\begin{array}{c}\text { Usia 10-12 thn } \\
\text { (Siku tekuk) }\end{array}$} & \multicolumn{2}{c}{$\begin{array}{c}\text { Usia 13-15 thn } \\
\text { (Angkat tubuh) }\end{array}$} & \multicolumn{2}{c}{$\begin{array}{c}\text { Usia 16-19 thn } \\
\text { (Angkat tubuh) }\end{array}$} \\
\cline { 2 - 10 } & F & $\%$ & F & $\%$ & F & $\%$ & F & $\%$ \\
\hline 5 & 1 & 12,5 & 2 & 20,0 & 0 & 0,0 & 0 & 0,0 \\
4 & 1 & 12,5 & 1 & 10,0 & 2 & 18,2 & 4 & 25,0 \\
3 & 3 & 37,5 & 5 & 50,0 & 6 & 54,5 & 7 & 43,8 \\
2 & 3 & 37,5 & 2 & 20,0 & 3 & 27,3 & 4 & 25,0 \\
1 & 0 & 0,0 & 0 & 0,0 & 0 & 0,0 & 1 & 6,3 \\
\hline Jumlah & 8 & 100 & 10 & 100 & 11 & 100 & 16 & 100 \\
\hline
\end{tabular}


Hasil tes gantung siku tekuk untuk kelompok usia 6-9 tahun, paling banyak mendapat nilai 3 sebanyak 3 orang (37,5\%) dengan waktu antara 3-8 detik dan nilai 2 sebanyak 3 orang $(37,5 \%)$ dengan waktu antara 9-21 detik. Hasil tes gantung siku tekuk pada kelompok usia 10-12 tahun, paling banyak mendapat nilai 3 sebanyak 5 orang (50\%) dengan waktu antara 15-30 detik. Hasil tes gantung angkat tubuh untuk kelompok usia 13-15 tahun, paling banyak mendapat nilai 3 sebanyak 6 orang $(54,5 \%)$ dengan angkatan antara 6-10 kali. Hasil tes gantung angkat tubuh pada kelompok usia 16-19 tahun, paling banyak mendapat nilai 3 sebanyak 7 orang $(43,8 \%)$ dengan angkatan antara 9-13 kali.

\section{c. Baring Duduk}

Hasil tes baring duduk pada anak usia 6-9 tahun dan usia 10-12 tahun dilakukan 30 detik, sedangkan tes baring duduk yang dilakukan pada anak usia 13-15 tahun dan 16-19 tahun dilakukan selama 60 detik.

\begin{tabular}{|c|c|c|c|c|c|c|c|c|}
\hline \multirow[t]{2}{*}{ Nilai } & \multirow{2}{*}{\multicolumn{2}{|c|}{$\begin{array}{l}\begin{array}{l}\text { Usia 6-9 thn } \\
\text { (kali) }\end{array} \\
\text { F }\end{array}$}} & \multirow{2}{*}{\multicolumn{2}{|c|}{$\begin{array}{l}\text { Usia } 10-12 \text { thn } \\
\text { (kali) }\end{array}$}} & \multicolumn{2}{|c|}{$\begin{array}{c}\text { Usia 13-15 thn } \\
\text { (kali) }\end{array}$} & \\
\hline & & & & & $\mathrm{F}$ & $\%$ & $\mathrm{~F}$ & $\%$ \\
\hline 5 & 2 & 25,0 & 2 & 20,0 & 5 & 45,5 & 10 & 62,5 \\
\hline 4 & 2 & 25,0 & 4 & 40,0 & 6 & 54,5 & 6 & 37,5 \\
\hline 3 & 4 & 50,0 & 4 & 40,0 & 0 & 0,0 & 0 & 0,0 \\
\hline 2 & 0 & 0,0 & 0 & 0,0 & 0 & 0,0 & 0 & 0,0 \\
\hline 1 & 0 & 0,0 & 0 & 0,0 & 0 & 0,0 & 0 & 0,0 \\
\hline Jumlah & 8 & 100 & 10 & 100 & 11 & 100 & 16 & 100 \\
\hline
\end{tabular}

Hasil tes baring duduk untuk kelompok usia 6-9 tahun, paling banyak mendapat nilai 3 yaitu sebanyak 4 orang (50\%) dengan perlakuan sebanyak 7-12 kali. Selanjutnya tes baring duduk pada kelompok usia 10-12 tahun, paling banyak mendapat nilai 4 dan 3 yaitu masing-masing 4 orang (40\%) dengan perlakuan sebanyak 18-22 kali dan 12-17 kali. Hasil tes baring duduk untuk kelompok usia 13-15 tahun, paling banyak mendapat nilai 4 yaitu sebanyak 6 orang (54,5\%) dengan perlakuan sebanyak 28-37 kali. Hasil tes baring duduk pada kelompok usia 16-19 tahun, paling banyak mendapat nilai 5 sebanyak 10 orang $(62,5 \%)$ dengan perlakuan sebanyak lebih dari 41 kali. 


\section{d. Loncat Tegak}

Hasil tes loncat tegak diperoleh berdasarkan capaian tinggi raihan dari 3 kali kesempatan loncat.

Tabel 5

Hasil TKJI Loncat Tegak

\begin{tabular}{ccccccccc}
\hline \multirow{2}{*}{ Nilai } & \multicolumn{2}{c}{$\begin{array}{c}\text { Usia 6-9 thn } \\
(\mathrm{cm})\end{array}$} & \multicolumn{2}{c}{$\begin{array}{c}\text { Usia 10-12 thn } \\
(\mathrm{cm})\end{array}$} & \multicolumn{2}{c}{$\begin{array}{c}\text { Usia 13-15 thn } \\
(\mathrm{cm})\end{array}$} & \multicolumn{2}{c}{ Usia 16-19 thn $(\mathrm{cm})$} \\
\cline { 2 - 9 } & $\mathrm{F}$ & $\%$ & $\mathrm{~F}$ & $\%$ & $\mathrm{~F}$ & $\%$ & $\mathrm{~F}$ & $\%$ \\
\hline 5 & 0 & 0,0 & 0 & 0,0 & 0 & 0,0 & 0 & 0,0 \\
4 & 0 & 0,0 & 1 & 10,0 & 1 & 9,1 & 3 & 18,8 \\
3 & 3 & 37,5 & 1 & 10,0 & 4 & 36,4 & 7 & 43,8 \\
2 & 5 & 62,5 & 7 & 70,0 & 5 & 45,5 & 6 & 37,5 \\
1 & 0 & 0,0 & 1 & 10,0 & 1 & 9,1 & 0 & 0,0 \\
\hline Jumlah & 8 & 100 & 10 & 100 & 11 & 100 & 16 & 100 \\
\hline
\end{tabular}

Hasil tes loncat tegak untuk kelompok usia 6-9 tahun, paling banyak mendapat nilai 3 sebanyak 3 orang $(37,5 \%)$ dengan loncatan antara 22-29 cm. Hasil tes loncat tegak pada kelompok usia-10-12 tahun, paling banyak mendapat nilai 2 sebanyak 7 orang $(70 \%)$ dengan loncatan antara $24-30 \mathrm{~cm}$. Kemudian hasil tes loncat tegak untuk kelompok usia 13-15 tahun, paling banyak mendapat nilai 2 sebanyak 5 orang $(45,5 \%)$ dengan loncatan antara 31-41 cm. Hasil tes loncat tegak pada kelompok usia 16-19 tahun, paling banyak mendapat nilai 3 sebanyak 7 orang $(43,8 \%)$ dengan loncatan antara $50-59 \mathrm{~cm}$.

\section{e. Lari Jarak Menengah}

Hasil tes lari jarak menengah diperoleh berdasarkan kelompok usia 6-9 tahun dan 10-12 tahun dengan lari 600 meter, dan untuk kelompok usia 13-15 tahun lari 1000 meter, sedangkan usia 16-19 tahun lari 1200 meter.

Tabel 6

Hasil TKJI Lari Jarak Menengah

\begin{tabular}{ccccccccc}
\hline \multirow{2}{*}{ Nilai } & \multicolumn{2}{c}{$\begin{array}{c}\text { Usia 6-9 thn } \\
(600 \mathrm{~m})\end{array}$} & \multicolumn{2}{c}{$\begin{array}{c}\text { Usia } 10-12 \text { thn } \\
(600 \mathrm{~m})\end{array}$} & \multicolumn{2}{c}{$\begin{array}{c}\text { Usia } 13-15 \text { thn } \\
(1000 \mathrm{~m})\end{array}$} & $\begin{array}{c}\text { Usia 16-19 thn }(1200 \\
\mathrm{m})\end{array}$ \\
\cline { 2 - 9 } & $\mathrm{F}$ & $\%$ & $\mathrm{~F}$ & $\%$ & $\mathrm{~F}$ & $\%$ & $\mathrm{~F}$ & $\%$ \\
\hline 5 & 0 & 0,0 & 0 & 0,0 & 0 & 0,0 & 0 & 0,0 \\
4 & 0 & 0,0 & 0 & 0,0 & 0 & 0,0 & 0 & 0,0 \\
3 & 4 & 50,0 & 2 & 20,0 & 2 & 18,2 & 0 & 0,0 \\
2 & 4 & 50,0 & 8 & 80,0 & 2 & 18,2 & 5 & 31,25 \\
1 & 0 & 0,0 & 0 & 0,0 & 7 & 63,6 & 11 & 68,75 \\
\hline Jumlah & 8 & 100 & 10 & 100 & 11 & 100 & 16 & 100 \\
\hline
\end{tabular}


Hasil tes lari 600 meter untuk kelompok usia 6-9 tahun, paling banyak mendapat nilai 2 dan 3 yaitu masing-masing 4 orang (50\%) dengan waktu 3'01'-3'45" dan 3'46"4'46". Selanjutnya tes lari 600 meter pada kelompok usia 10-12 tahun, paling banyak mendapat nilai 2 yaitu sebanyak 8 orang (80\%) dengan waktu 2'46"'-3'44". Kemudian hasil tes lari 1000 meter untuk kelompok usia 13-15 tahun, paling banyak mendapat nilai 1 sebanyak 7 orang $(63,6 \%)$ dengan waktu kurang dari 6'50'. Hasil tes lari 1200 meter pada kelompok usia 16-19 tahun, paling banyak mendapat nilai 1 sebanyak 11 orang $(68,75 \%)$ dengan waktu kurang dari 6’34'.

Berarti dapat disimpulkan bahwa tingkat kebugaran jasmani anak putra di Panti Sosial asuhan Anak William Booth Medan berada pada klasifikasi “sedang”, seperti pada gambar berikut:

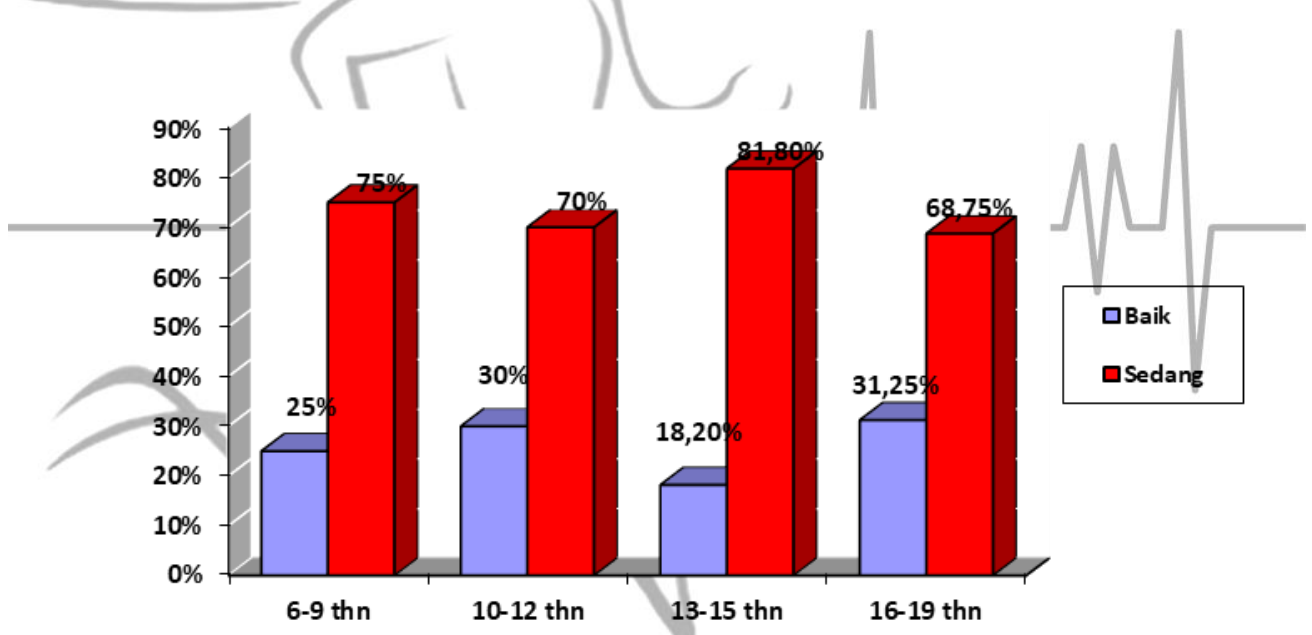

Gambar 1. Persentase Klasifikasi Nilai Tes TKJI Berdasarkan Kelompok Umur

\section{PEMBAHASAN PENELITIAN}

Hasil Tes Kebugaran Jasmani Indonesia menunjukkan bahwa tingkat kebugaran jasmani anak putra di PSAA William Booth medan berada dalam klasifikasi "Sedang". Dalam penelitian ini diperoleh jumlah persentase pada anak putra kelompok umur 6-9 tahun yaitu $75 \%$ sebanyak 6 orang, pada kelompok umur 10-12 tahun sebesar 70\% sebanyak 7 orang, pada kelompok umur 13-15 tahun diperoleh 81,8\% sebanyak 9 orang dan pada kelompok umur 16-19 tahun diperoleh 68,75\% sebanyak 11 orang.

Tingkat Kebugaran Jasmani Kebugaran jasmani merupakan faktor utama bagi setiap manusia untuk dapat melaksanakan aktifitas sehari-harinya dengan baik. Adapun faktor-faktor yang mempengaruhi kebugaran jasmani seseorang adalah olahraga atau 
latihan, makanan dan istirahat yang cukup. Karakteristik dikatakan bugar yaitu apabila memiliki fisik yang aktif bergerak, inisiatif tinggi, memiliki mental yang kuat, percaya diri, berpikiran positif, kreatif dan tidak sering sakit. Dan faktor-faktor yang mempengaruhi kebugaran jasmani seseorang meliputi makanan, olahraga atau latihan dan istirahat yang cukup (Muhajir, 2007:58 ).

Sementara, jadwal kegiatan setiap hari yang sudah ditetapkan oleh pihak panti asuhan begitu padat. Mulai dari anak-anak bangun pagi, mereka langsung mengerjakan pekerjaannya masing-masing, mandi dan kemudian sarapan. Setelah itu, mereka berangkat ke sekolah dengan berjalan kaki. Kemudian mereka pulang sekolah, makan siang kemudian istirahat (tidur) siang. Pada sore hari mereka bangun, kemudian belajar, melakukan pekerjaannya masing-masing seperti menyapu halaman dan membersihkan pekarangan. Kemudian, pada malam hari mereka makan, belajar dan diteruskan dengan doa malam lalu mereka istirahat malam. Sehingga, sedikit waktu yang mereka manfaatkan untuk melakukan suatu aktivitas/olahraga yang/berguna untuk meningkatkan kebugaran meraka. Kemudian mereka hanya berolahraga di sekolah karena adanya mata pelajaran olahraga yang mereka ikuti. Oleh karena itu, tingkat kebugaran anak-anak tergolong sedang.

Adanya aktifitas di luar jadwal kegiatan yang dilakukan anak Putra Panti Sosial Asuhan Anak William Booth Medan. Seperti adanya undangan kepada pihak panti, supaya anak-anak menghadiri suatu acara atau adanya pengunjung yang datang untuk mengajak makan bersama anak-anak. Sehingga, semakin sedikit waktu luang mereka yang seharusnya bisa dimanfaatkan untuk melakukan suatu aktivitas olahraga yang berguna untuk meningkatkan kebugaran jasmani anak-anak. Hal ini menyebabkan tingkat kebugaran jasmani anak-anak kurang maksimal, sehingga tergolong sedang.

Latihan kondisi fisik (physical conditioning) memegang peranan yang sangat penting untuk mempertahankan atau meningkatkan derajat kebugaran jasmani (physical fitness). Derajat kebugaran jasmani seseorang sangat menentukan kemampuan fisiknya dalam melaksanakan tugas-tugasnya sehari-hari. Semakin tinggi derajat kebugaran jasmani seseorang kian tinggi pula kemampuan kerja fisiknya. Dengan kata lain, hasil kerjanya kian produktif jika kebugaran jasmaninya kian meningkat (Muhajir, 2007:57). Akan tetapi, anak putera panti sosial asuhan anak william booth medan tidak memiliki jadwal khusus untuk latihan kondisi fisik juga sarana dan prasarana kurang memadai 
tetapi mereka tetap bermain, melakukan suatu permainan yang mereka ketahui dengan memanfaatkan sarana yang ada. Sehingga, kebugaran jasmani mereka tergolong sedang.

Faktor latihan dan olahraga punya pengaruh yang besar terhadap peningkatan kebugaran jasmani seseorang. Menurut Abdul Kadir Ateng (1992:68) "Seseorang yang secara teratur berlatih sesuai dengan keperluannya dan memperoleh kebugaran jasmani dari padanya disebut terlatih. Sebaliknya, seseorang yang membiarkan ototnya lemas tergantung dan berada dalam kondisi fisik yang buruk disebut tidak terlatih”. Sementra, yang dilakukan oleh anak putera panti sosial asuhan anak william booth medan hanyalah bermain. Melakukan permainan yang mereka tentukan sendiri peraturannya dan tidak terorganisir. Akan tetapi, meskipun mereka tidak terlatih, mereka tetap melaksanakan permainan. Dengan kata lain mereka tidak mebiarkan otot-ototnya lemas dan tidak berada dalam kondisi yang buruk. Sehingga, tingkat kebugaran jasmani mereka tergolong sedang.

\section{KESIMPULAN}

Berdasarkan hasil penelitian, maka dapat ditarik kesimpulan bahwa tingkat kebugaran jasmani anak putra di Panti Sosial Asuhan Anak William Booth Medan berada dalam klasifikasi sedang.

\section{Daftar Pustaka}

Ateng, Abdul Kadir. 1992. Azas dan Landasan Pendidikan Jasmani. Jakarta. Depdikbud Dirjen Dikti.

Harsono. 1998. Coaching dan Aspek-Aspek Psikologi Dalam Coaching. Jakarta. CV. Tombak Kusuma.

Hasnan, Said. 1975. Tes Kesegaran Jasmani indonesia. Jakarta. Departemen Pendidikan dan Kebudayaan. Rineka Cipta.

Kepmensos Republik Indonesia No:59/Huk/2002. Tentang Organisasi dan Tata Kerja Panti Sosial Di Lingkungan Departemen Sosial.

Lutan, Rusli. 2002. Belajar Keterampilan Motorik Pengatar Teori dan Metode. Jakarta. P2LPTK Dirjen Dikti Depdikbud.

Muhajir. 2007. Pendidikan Jasmani Olahraga dan Kesehatan. Jakarta. Erlangga.

Nurhasan. 2001. Tes dan Pengukuran Dalam Pendidikan Jasmani : Prinsip-Prinsip dan Penerapannya. Jakarta. Direktorat Jenderal Olahraga, Depdiknas.

Pusat Pengembangan Kualitas Jasmani Kementerian Pendidikan Nasional. 2010. Pedoman Teknis Pemetaan Kebugaran Jasmani pelajar. Jakarta. Depdikbud.

Undang-Undang Republik Indonesia No. 35 tahun 2014. Tentang Perubahan Atas UUD NO. 23 Tahun 2002 tentang Perlindungan Anak.

Undang-Undang Republik Indonesia No. 4/1979, Tentang kesejahteraan anak Bab 1 pasal 1. 